\title{
EVALUASI USABILITY WEBSITE BERITA ONLINE MENGGUNAKAN METODE HEURISTIC EVALUATION
}

\author{
${ }^{1}$ Tengku Khairil Ahsyar, ${ }^{2}$ Dinda Afani \\ ${ }^{1,2}$ Program Studi Sistem Informasi, Fakultas Sains dan Teknologi, UIN SUSKA Riau, \\ Jl. HR Soebrantas, KM. 18.5, No. 155, Simpang Baru, Pekanbaru, Indonesia, 28293. \\ Email: 'tengkukhairil@uin-suska.ac.id, 2dindaafani86@gmail.com.
}

\begin{abstract}
ABSTRAK
Website berita online merupakan salah satu media penting untuk memperluas penyampaian informasi melalui dunia maya. Banyak masyarakat dipermudah mencari berita-berita terbaru dengan memanfaatkan website berita online. Terkadang tidak selamanya website berita online tersebut menyajikan informasi-informasi yang mudah dipahami oleh masyarakat. Permasalahan yang sering ditemui yakni banyak website berita online tidak memperhatikan masalah usability, sehingga tidak sedikit pengguna website tersebut kebingungan, jenuh, bahkan tersesat dengan tampilan yang tidak sesuai. Terlebih lagi, banyak website-website berita online tidak pernah melakukan evaluasi usability pada website tersebut. Fokus penelitian ini melakukan evaluasi usability pada website berita online serta memberikan rekomendasi solusi. Metode yang digunakan untuk menemukan masalah usability adalah Heuristic. Penelitian ini melibatkan lima orang pakar usability sebagai evaluator untuk menilai website berita online. Hasil perhitungan menunjukkan proporsi masalah tertinggi yaitu pada prinsif Aesthetic and Minimalist Design sebesar 22\%. Permasalahan tersebut terkait desain gambar yang kurang eye catching dengan topik, penyajian informasi pada fungsi pencarian yang kurang jelas, pembatas antar menu tidak jelas, artikel terlihat tidak rapi, dan yang terakhir yakni desain website yang terlalu penuh dengan informasi yang menyebabkan tidak fokusnya pengguna website tersebut. Penelitian ini juga menghasilkan rekomendasi solusi dari daftar permasalahan usability yang dapat dijadikan sebagai rujukan bagi tim pengembang website dalam melakukan perbaikan usability website.
\end{abstract}

Kata Kunci: evaluasi, heuristic, usability, website berita online

\section{A. PENDAHULUAN}

Banyak kemajuan diberbagai aspek kehidupan manusia terutama pada sektor bisnis disebabkan oleh perkembangan teknologi informasi yang semakin cepat [1]. PT. Citra Media Bertuah merupakan perusahaan yang berhasil menerapkan teknologi informasi pada saat ini dalam dunia bisnis, khususnya pada bidang media dan komunikasi. Perusahaan ini membangun sebuah website media online dengan domain bertuahpos.com yang merupakan portal berita dan bisnis. $75 \%$ konten website bertuahpos.com berisikan informasi yang berhubungan dengan dunia ekonomi bisnis, sedangkan $25 \%$ berisi informasi yang bersifat umum mengenai kondisi terkini yang bersifat lokal maupun nasional.

Sejak pertama kali dibangun pada tahun 2012, website bertuahpos.com belum pernah dilakukan evaluasi terhadap usability. Hanya saja evaluasi yang dilakukan saat ini dilakukan berdasarkan saran dan kritik dari beberapa pengguna dan tim pengelola website. Hasil tampungan saran dan kritik dari pengguna tersebut kemudian dilakukan diskusi lewat meeting untuk dipertimbangkan. Selanjutnya dilakukan perbaikan. Hal ini akan sering dilakukan jika pihak pengelola tidak fokus dalam melakukan evaluasi secara menyeluruh terhadap tampilan yang sesuai dengan keinginan pengguna.

Perlunya melakukan evaluasi dengan menggunakan metode-metode atau standar tertentu dapat mengurangi dan mengetahui kondisi website saat ini dengan maksimal. Tanpa evaluasi sesuai standar maka tidak akan diketahui bagaimana kondisi website tersebut dalam pelaksanaannya sejak awal dibangun [2]. Evaluasi yang paling relevan untuk sebuah sistem yakni dengan melakukan identifikasi faktor usability [3]. Dengan melakukan evaluasi dari aspek usability dapat meningkatkan usability sebuah website [4].

Ketika pengguna mengunjungi sebuah website, biasanya pengguna tersebut sangatlah memperhatikan masalah usability [5], terutama pada saat pertama kali pengguna tersebut melakukan kunjungan. Usability merupakan syarat mutlak pada sebuah website. Jika sebuah website tidak usable, maka pengunjung biasanya akan meninggalkan website tersebut [6]. Usability dapat membuat pengguna menjadi senang terhadap sebuah website atau dapat pula menjadi frustasi [7]. Website dengan tingkat usability yang tinggi membuat sebuah website tersebut dapat menjadi popular [8]. Hal tersebut yang mendasari penelitian ini melakukan evaluasi dari segi usability. 
Salah satu metode evaluasi yang berhubungan dengan usability adalah Heuristic [6]. Evaluasi Heuristic merupakan teknik pengujian untuk menyelesaikan masalah usability berdasarkan aspek desain user interface dan dapat membuat keputusan dengan cepat serta efisien [9]. Evaluasi Heuristic ini pertama kali diperkenalkan oleh Nielsen dan Molich pada tahun 1990. Tujuan utama dari evaluasi Heuristic adalah untuk mengidentifikasi masalah terkait dengan usability website [10]. Metode ini diklasifikasikan sebagai teknik evaluasi analitik kualitatif [11]. Prinsip yang terdapat pada metode ini berhubungan dengan sepuluh prinsip, yaitu: (1) visibility of system status; (2) match between system and the real world; (3) use control and freedom; (4) consistency and standards; (5) error prevention; (6) recognition rather than recall; (7) flexibility and efficiency of use; (8) aesthetic and minimalist design; (9) help user recognize, dialogue, and recovers from errors; dan (10) help and document [12].

Tidak semua prinsip Heuristic dapat digunakan untuk melakukan evaluasi. Prinsip-prinsip yang digunakan tentunya yang berkaitan dengan permasalahan usability sebuah software [7], seperti dalam penelitian [13] yang hanya menggunakan tujuh dari sepuluh prinsif. Pada setiap prinsip Heuristic tidak memiliki pedoman yang menjadi tolak ukur untuk mengevaluasi suatu objek, sehingga evaluator dapat menafsirkannya dengan cara yang berbeda dan menghasilkan hasil yang berbeda [14]. Pada penelitian ini hanya menggunakan delapan prinsip, tidak termasuk pada prinsip error prevention dan help and document.

Evaluasi Heuristic memiliki kekuatan diantaranya: (1) sangat baik digunakan sebagai teknik evaluasi karena lebih mudah untuk menemukan masalah usability yang muncul [15]; (2) metode ini relatif lebih murah dan besar manfaatnya [12]; (3) evaluator yang digunakan dalam evaluasi Heuristic yaitu ahli dibidang usability [16] sehinggga data yang diperoleh akan lebih akurat; dan (4) metode ini banyak digunakan dalam mengukur tingkat kenyamanan pengguna [17].

Berdasarkan penjelasan di atas, maka penelitian ini mengangkat topik evaluasi usability pada website website berita online dengan mengangkat studi kasus pada PT. Citra Media Bertuah dengan domain website bertuahpos.com menggunakan metode Heuristic. Dari evaluasi ini diharapkan dapat dijadikan rujukan bagi tim pengembang website berita online dalam melakukan perbaikan usability sehingga dapat mencapai kepuasan pengguna.

\section{B. METODOLOGI PENELITIAN}

Dalam penelitian ini terdapat beberapa tahapan dalam melakukan proses evaluasi usability pada website berita online bertuahpos.com. Sebelum melangkah pada tahapan inti dalam penelitian ini, langkah yang paling awal dilakukan adalah perencanaan dan studi pendahuluan. Hal ini dilakukan untuk mempersiapkan proses tahapan inti dalam penelitian ini. Setelah melakukan perencanaan dengan matang, dilanjutkan dengan pengumpulan data awal. Proses pengumpulan data awal dilakukan dengan cara observasi dan wawancara langsung kepada pihak PT. Citra Media Bertuah. Kegiatan ini dilakukan untuk mendapatkan fakta-fakta otentik dan informasi yang langsung berasal dari tempat penelitian.

Setelah dilakukan proses perencanaan dan pengumpulan data awal, tahap berikutnya dilakukan identifikasi permasalahan. Hasil tersebut kemudian dijadikan sebagai acuan dalam merumuskan permasalahan utama yang nantinya menjadi tujuan utama yakni melakukan evaluasi terhadap website bertuahpos.com dengan menggunakan metode Heuristic serta memberikan solusi dari rekomendasi yang telah dibuat.

Setelah melakukan tahapan awal, langkah berikutnya adalah melakukan proses inti dari penelitian ini, diantaranya sebagai berikut:

\section{B.1. Identifikasi Variabel}

Pada tahap ini, ditentukan variabel-variabel dari prinsip-prinsip Heuristic. Adapun prinsip yang digunakan pada penelitian ini dibatasi hanya 8 prinsip, yakni: (1) visibility of system status; (2) match between system and the real world; (3) use control and freedom; (4) consistency and standards; (5) recognition rather than recall; (6) flexibility and efficiency of use; (7) aesthetic and minimalist design; (8) help user recognize, dialogue, and recovers from errors. Prinsip ini dilibatkan karena menyesuaikan dengan permasalahan usability yang ada pada studi kasus [7]. Untuk mempermudah proses analisis, ke delapan prinsip tersebut diberi kode H1 sampai H8 seperti pada Tabel 1 Kode Heuristic.

\section{B.2. Mengategorikan Masalah}

Pada tahapan ini, menemukan masalah-masalah yang berhubungan dengan usability. Adapun permasalahan yang berhubungan dengan usability ditemukan berdasarkan hasil penilaian Guideline Heuristic Evaluation (GHE) dari para pakar. Kemudian masalah tersebut dirangkum pada sebuah tabel. 
Pada penelitian ini melibatkan 5 orang pakar yang terdiri dari 1 orang dari Service Quality Tester, 2 orang dari dosen yang memiliki kepakaran dibidang Interaksi Manusia dan Komputer, serta 2 orang dari perusahaan pengembang perangkat lunak yang berprofesi sebagai programmer dan designer yakni dari Code Focus Developer dan Java Source Code Developer. Menurut Nielsen [18], hasil pengujian pada evaluasi usability sebuah website idealnya tidak lebih dari lima orang evaluator.

Sedangkan prosedur pengujian yang dilakukan berdasarkan Guideline Heuristic Evaluation, yakni: (1) Evaluator menerima berkas yang berisi GHE, lembar persetujuan evaluator, dan lembar penilaian evaluasi Heuristic; (2) Evaluator mengisi data pada lembar persetujuan evaluator; (3) Evaluator melakukan eksplorasi awal website bertuahpos.com agar terbiasa dengan interface website sebelum dilakukan pengujian; (4) Pengujian dimulai, evaluator melakukan eksplorasi dan usability inspection Heuristic evaluation website bertuahpos.com. Pada langkah ini tidak boleh ada interupsi dari moderator atau pihak lain; (5) Setelah selesai mengevaluasi, evaluator mengisi dan memberi penilaian pada permasalahan yang muncul yang berhubungan dengan usability disertai rekomendasi solusi; dan yang terakhir, (6) Evaluator memberikan kembali berkas yang sudah diisi.

Untuk melihat daftar permasalahan yang telah ditemukan oleh para pakar, dapat dilihat pada Tabel 2 Kategori masalah usability.

\section{B.3. Penghitungan Masalah Usability}

Pada tahap ini melakukan penghitungan proporsi masing-masing prinsip Heuristic setalah melakukan pengkategorian masalah-masalah yang berhubungan dengan Heuristic. Pada tahapan ini dapat diketahui prinsip-prinsip yang mana yang paling banyak diidentifikasi oleh evaluator beserta masing-masing proporsinya.

\section{B.4. Perbandingan Model Nielsen}

Pada tahap ini, kategori permasalahan usablity yang telah ditemukan selanjutnya dibandingkan dengan model Nielsen (1992). Hal ini dilakukan untuk membuktikan apakah penelitian ini telah sesuai atau tidak. Langkah-langkah proses pada tahap ini merujuk pada penelitian [19].

\section{B.5. Presentase Kombinasi Evaluator}

Setelah diketahui hasil kombinasi evaluator, selanjutnya dihitung rata-rata dan persentase jumlah Heuristic untuk setiap kelompok tersebut. Hasil dari perhitungan persentase jumlah masalah usability yang ditemukan dapat dilihat pada Tabel 5 .

\section{B.6. Rekomendasi Solusi}

Pada tahap ini, menentukan rekomendasi dari hasil yang telah didapatkan berupa solusi dari masing-masing permasalahan. Rekomendasi ini diharapkan dapat dijadikan acuan kepada pihak pengembang website untuk dapat memperbaiki kelemahan-kelemahan yang berhubungan dengan usability.

\section{HASIL DAN PEMBAHASAN \\ C.1. Identifikasi Variabel}

Identifikasi variabel ditentukan pada 8 prinsip Heuristic, yakni: (1) visibility of system status; (2) match between system and the real world; (3) use control and freedom; (4) consistency and standards; (5) recognition rather than recall; (6) flexibility and efficiency of use; (7) aesthetic and minimalist design; (8) help user recognize, dialogue, and recovers from errors. Untuk mempermudah proses analisis, ke delapan prinsip tersebut ditandai dengan pemberian kode dari H1 sampai H8 seperti yang terlihat pada Tabel 1 Kode Heuristic.

Pada Tabel 1 tersebut, terdapat tiga kolom yang terdiri dari Kode, Heuristic, dan Keterangan. Untuk kolom Kode, berisi kode dari H1 sampai dengan H8 sesuai dengan jumlah prinsip yang terkait dalam penelitian ini. Sedangkan untuk kolom Heuristic menampilkan ke delapan prinsip yang terlibat dalam penelitian ini. Terakhir pada kolom Keterangan, berisikan tentang keterangan atau deskripsi dari masing-masing prinsip yang digunakan.

\section{C.2. Mengategorikan Masalah}

Kategori permasalahan yang berhubungan dengan usability pada terdapat sebanyak 23 permasalahan. Permasalahan ini didapatkan dari hasil penilaian terhadap website bertuahpos.com setelah para pakar yang ditunjuk sebagai evaluator melakukan penilaian terhadap website tersebut. Tabel 2 merupakan daftar masalah-masalah usability yang ditemukan berdasarkan hasil penilaian GHE oleh para evaluator. Masing-masing masalah tersebut digabungkan dengan masing-masing kode Heuristic.

\section{C.3. Perhitungan Masalah Usability}

Selanjutnya menghitung proporsi masingmasing prinsip Heuristic dari Tabel 2 sebagaimana yang ditampilkan pada Tabel 3 mengenai perhitungan masalah pada usability.

Berdasarkan perhitungan pada Tabel 3 tersebut, dapat dilihat bahwa kategori masalah usability yang paling banyak diidentifikasi oleh evaluator adalah prinsip dengan kode $\mathrm{H} 7$ yaitu aesthetic and minimalist design dengan proporsi $22 \%$ dari dari total 23 masalah yang ditemukan pada website bertuahpos.com. Sedangkan persentase kedua 
Jurnal Ilmiah Rekayasa dan Manajemen Sistem Informasi, Vol. 5, No. 1, Februari 2019, Hal. 34-41

e-ISSN 2502-8995, p-ISSN 2460-8181

terbanyak adalah $\mathrm{H} 1$ yaitu visibility of system status dengan proporsi $17 \%$. Sedangkan yang terendah adalah $\mathrm{H} 8$ yaitu help users recognize, dialogue, and recovers from errors dengan proporsi $4 \%$.

\section{C.4. Perbandingan Model Nielsen}

Dari kategori masalah usability yang telah ditemukan, pada tahap ini dilakukan perbandingan dengan model Nielsen (1992) untuk membuktikan apakah telah sesuai atau tidak. Pada setiap kelompok tersebut diambil kombinasi evaluator secara acak sebanyak tiga kali. Hasil dari pengambilan evaluator secara acak ini dapat dilihat pada Tabel 4. Untuk Jumlah $=1$, evaluator yang terpilih yakni 1, 4, dan 2, dengan hasil Heuristic untuk evaluator 1 dengan jumlah Heuristic sebanyak 6, yakni: H1, H2, H4, H5, H6, dan H7. Evaluator 4 dengan jumlah Heuristic 5, yakni: H1, H2, H3, H5, dan H7. Sedangkan untuk evaluator 2 dengan jumlah Heuristic 3, yakni: H1, H4, dan H7. Untuk melihat jumlah kategori setiap kelompok, dapat dilihat pada Tabel 4.

\section{C.5. Persentase Kombinasi Evaluator}

Setelah dilakukan perbandingan Model Nielsen dan diketahui hasil kombinasi evaluator, selanjutnya dihitung rata-rata dan persentase jumlah Heuristic untuk setiap kelompok tersebut. Hasil dari perhitungan persentase jumlah masalah usability yang telah ditemukan dapat dilihat pada Tabel 5 . Untuk melihat perbandingan model Nielsen dalam bentuk diagram, dapat dilihat pada Gambar 1 . Berdasarkan Gambar 1, terlihat bahwa penelitian ini sudah sesuai dengan model Nielsen. Hal ini dibuktikan dengan nilai yang berada pada kisaran angka dengan selisih yang tidak terlalu jauh. Evaluator cenderung menilai prinsip-prinsip dengan hasil yang tidak jauh berbeda. Hal ini membuktikan Heuristic mampu mengidentifikasi masalah usability dengan melibatkan lima orang evaluator ahli.

\section{C.6. Rekomendasi Solusi}

Permasalahan tertinggi pada penelitian ini adalah prinsip aesthetic and minimalist design dengan persentase sebesar 22\%. Dari hasil tersebut, berikut permasalahan dan solusi yang di rekomendasikan: (1) Apabila data tidak ditemukan pada fungsi pencarian, informasi yang disajikan tidak terlihat dengan jelas, karena jarak pemasangan iklan dan informasi hasil pencarian terlalu dekat, sehingga membuat pengguna menjadi bingung (Gambar 2). Solusi, sebaiknya diberi jarak antara informasi (hasil pencarian) dengan iklan, kurang lebih 5 baris kalimat; (2) Pada menu utama pembatas antara menu tidak terlihat dengan jelas, serta artikel terlihat tidak rapi karena menggunakan rata-kiri (Gambar 3). Sebaiknya pembatas menu utama dibuat dengan warna yang lebih kontras dari warna background. Contohnya warna putih, karena warna putih merupakan warna netral, sehingga pengguna dapat membedakannya. Sedangkan untuk artikel yang terlihat tidak rapi, sebaiknya menggunakan rata kiri-kanan (align justify) agar terlihat rapi dan nyaman saat pengguna membacanya; (3) Sebagian gambar dan judul berita tidak sesuai (eye catching). Hal ini dapat mempengaruhi keinginan pembaca (Gambar 4). Sebaiknya gambar dan judul berita lebih disesuaikan; (4) Website memiliki desain yang terlalu penuh (padat) dengan informasi yang berupa teks, sehingga membuat pengguna menjadi cepat jenuh (Gambar 5). Sebaiknya desain tampilan utama website lebih meminimalisir informasi-informasi yang berlebihan. Contohnya pada kategori berita populer, dapat dibatasi dengan jumlah 3 sampai 5 berita saja.

Hasil ini diharapkan dapa dijadikan acuan bagi pihak PT. Citra Media Bertuah dalam perbaikan website bertuahpos.com kedepannya.

Tabel 1. Kode Heuristic

\begin{tabular}{|c|c|c|}
\hline Kode & Heuristic & Keterangan \\
\hline H1 & Visibility of System Status & $\begin{array}{l}\text { Sistem harus selalu menginformasikan pada pengguna apa yang sedang terjadi, melalui } \\
\text { pesan yang baik dan waktu yang sesuai. }\end{array}$ \\
\hline $\mathrm{H} 2$ & $\begin{array}{l}\text { Match Between System and The } \\
\text { Real World }\end{array}$ & $\begin{array}{l}\text { Berbicara dengan bahasa pengguna. Dialog seharusnya menggunakan bahasa yang } \\
\text { dipahami oleh pengguna. Penggunaan singkatan dan bahasa yang tidak jelas juga harus } \\
\text { dihindari karena bisa disalah-tafsirkan sehingga membuat pengguna keliru. }\end{array}$ \\
\hline $\mathrm{H} 3$ & Use Control and Freedom & Pengguna harus dapat secara bebas memilih dan melakukan pekerjaan (sesuai kebutuhan). \\
\hline $\mathrm{H} 4$ & Consistency and Standards & $\begin{array}{l}\text { Menghindarkan pengguna dari rasa ragu-ragu saat menggunakan suatu perintah atau fungsi } \\
\text { untuk pertama kali. }\end{array}$ \\
\hline H5 & Recognat-ion Rather than Recall & $\begin{array}{l}\text { Pengguna tidak perlu mempertanyakan lagi mengenai perbedaan pemahaman pada sebuah } \\
\text { kata dan kalimat. }\end{array}$ \\
\hline H6 & Flexibility and Efficient of Use & $\begin{array}{l}\text { Bagaimana membuat sebuah sistem yang mengakomodasi pengguna yang sudah ahli dan } \\
\text { pengguna yang masih pemula. }\end{array}$ \\
\hline $\mathrm{H} 7$ & Aesthetic and Minimalist Design & $\begin{array}{l}\text { Sebuah dialog tidak boleh mengandung konten atau informasi yang tidak relevan dan tidak } \\
\text { diperlukan. Setiap komponen harus mengandung arti dan fungsi yang sesuai dengan } \\
\text { keperluan sistem tersebut. }\end{array}$ \\
\hline H8 & $\begin{array}{l}\text { Help Users Recognize, Dialogue, } \\
\text { and Recovers From Errors }\end{array}$ & $\begin{array}{l}\text { Instruksi dan informasi pada sistem harus mudah diakses dan jelas terlihat pada saat } \\
\text { dibutuhkan. }\end{array}$ \\
\hline
\end{tabular}


Tabel 2. Kategori masalah usability

\begin{tabular}{|c|c|c|c|}
\hline No. & Masalah usability yang Ditemukan & Evaluator & Kode Heuristic \\
\hline 1. & $\begin{array}{l}\text { Prinsip feedback tidak diterapkan sepenuhnya pada website bertuahpos.com, masih ada beberapa } \\
\text { konten yang memiliki feedback kurang baik. Contohnya konten berita terkini. }\end{array}$ & 1 & H1 \\
\hline 2. & $\begin{array}{l}\text { Penggunaan bahasa tidak konsisten seperti pada menu bar pada halaman utama yang } \\
\text { menggunakan Bahasa Indonesia dan Bahasa Inggris. }\end{array}$ & 1 & $\mathrm{H} 2$ \\
\hline 3. & $\begin{array}{l}\text { Tingkat konsistensi pada laman bertuahpos.com masih cukup rendah, seperti penggunaan bahasa } \\
\text { pada menu utama yang menggunakan Bahasa Indonesia dan Bahasa Inggris. }\end{array}$ & 1 & $\mathrm{H} 4$ \\
\hline 4. & Proses pencarian data pada fungsi pencarian data tergolong lambat dalam mencari data. & 1 & H5 \\
\hline 5. & $\begin{array}{l}\text { Sistem memerlukan waktu yang cukup lama (sekitar satu menit) untuk mendapatkan informasi } \\
\text { yang diinginkan. Contohnya proses membuka laman bertuahpos.com serta proses fungsi } \\
\text { pencarian data. }\end{array}$ & 1 & H6 \\
\hline 6. & Sebagian gambar dan judul berita tidak sesuai (eye catching). & 1 & $\mathrm{H} 7$ \\
\hline 7. & Sistem tidak jelas dalam menginformasikan keberadaan user sedang berada di suatu menu. & 2 & H1 \\
\hline 8. & Penggunaan bahasa tidak konsisten. & 2 & $\mathrm{H} 4$ \\
\hline 9. & Bertuahpos.com memiliki desain yang terlalu penuh informasi, sehingga membuat jenuh user. & 2 & $\mathrm{H} 7$ \\
\hline 10. & $\begin{array}{l}\text { Penggunaan bahasa tidak konsisten seperti pada menu bar pada halaman utama yang } \\
\text { menggunakan Bahasa Indonesia dan Bahasa Inggris. }\end{array}$ & 3 & $\mathrm{H} 4$ \\
\hline 11. & Fungsi pencarian pada website tergolong lama pada saat digunakan. & 3 & H6 \\
\hline 12. & $\begin{array}{l}\text { Pada kolom komentar tidak terdapat berbagai akun untuk user memberikan komentar hanya } \\
\text { tersedia akun Facebook. }\end{array}$ & 3 & H6 \\
\hline 13. & Pada menu bar pembatas antar menu tidak terlihat jelas. & 3 & H8 \\
\hline 14. & Artikel terlihat tidak rapi. Karena menggunakan rata kiri (Align Left). & 3 & H8 \\
\hline 15. & $\begin{array}{l}\text { Pada saat data tidak ditemukan pada fungsi pencarian, sistem tidak memberikan informasi secara } \\
\text { jelas dan tidak familiar. }\end{array}$ & 3 & $\mathrm{H} 8$ \\
\hline 16. & $\begin{array}{l}\text { Pada saat user memilih menu, warna tulisan maupun background menu tidak berubah hanya } \\
\text { menampilkan judul menu di atas content. }\end{array}$ & 4 & H1 \\
\hline 17. & $\begin{array}{l}\text { Ketidaksesuaian antara salah satu menu utama dengan isi. Contohnya pada menu "travelling" } \\
\text { terdapat artikel dengan judul "ingin hidup tenang menikahlah". }\end{array}$ & 4 & $\mathrm{H} 2$ \\
\hline 18. & Tidak adanya button "back to top" pada website. & 4 & $\mathrm{H} 3$ \\
\hline 19. & $\begin{array}{l}\text { Menu "suara anda" tidak sesuai dengan judul karena isi di dalamnya lebih mirip dengan artikel } \\
\text { kiriman pembaca. }\end{array}$ & 4 & H5 \\
\hline 20. & Pada bagian konten "suara anda" isi artikel tidak sesuai dengan judul. & 4 & $\mathrm{H} 7$ \\
\hline 21. & Kurangnya informasi terhadap suatu berita sehingga dapat tergolong ke dalam berita populer. & 5 & H1 \\
\hline 22. & Penggunaan bahasa tidak konsisten. & 5 & $\mathrm{H} 2$ \\
\hline 23. & Link pada bagian "Breaking News" terlalu cepat berganti sebelum user membuka link. & 5 & $\mathrm{H} 3$ \\
\hline
\end{tabular}

Tabel 3. Perhitungan masalah usability

\begin{tabular}{clccc}
\hline Kode Heuristic & Heuristic & Frekuensi & Persentase & Persentase Kumulatif \\
\hline H1 & Visibility of System Status & 4 & $17 \%$ & $17 \%$ \\
H2 & MatcBetween System and The Real World & 3 & $13 \%$ & $30 \%$ \\
H3 & Use Control and Freedom & 2 & $9 \%$ & $39 \%$ \\
H4 & Consistency and Standards & 3 & $13 \%$ & $52 \%$ \\
H5 & Recognation Rather than Recall & 2 & $9 \%$ & $61 \%$ \\
H6 & Flexibility and Efficient of Use & 3 & $13 \%$ & $74 \%$ \\
H7 & Aesthetic and Minimalist Design & 5 & $22 \%$ & $96 \%$ \\
H8 & Help Users Recognize, Dialogue, and Recovers From Errors & 1 & $4 \%$ & $100 \%$ \\
\hline Jumlah & & 23 & $100 \%$ & \\
\hline
\end{tabular}

Tabel 4. Jumlah kategori setiap kelompok

\begin{tabular}{cllc}
\hline Jumlah & Evaluator & Heuristic & Jumlah Heuristic \\
\hline 1 & 1 & $\mathrm{H} 1, \mathrm{H} 2, \mathrm{H} 4, \mathrm{H} 5, \mathrm{H} 6, \mathrm{H} 7$ & 6 \\
& 4 & $\mathrm{H} 1, \mathrm{H} 2, \mathrm{H} 3, \mathrm{H} 5, \mathrm{H} 7$ & 5 \\
2 & 2 & $\mathrm{H} 1, \mathrm{H} 4, \mathrm{H} 7$ & 3 \\
& 5,3 & $\mathrm{H} 1, \mathrm{H} 2, \mathrm{H} 3, \mathrm{H} 4, \mathrm{H} 6, \mathrm{H} 8$ & 6 \\
& 2,1 & $\mathrm{H} 1, \mathrm{H} 2, \mathrm{H} 4, \mathrm{H} 5, \mathrm{H} 6, \mathrm{H} 7$ & 6 \\
3 & 3,4 & $\mathrm{H} 1, \mathrm{H} 2, \mathrm{H} 3, \mathrm{H} 4, \mathrm{H} 5, \mathrm{H} 6, \mathrm{H} 7, \mathrm{H} 8$ & 8 \\
& $5,3,2$ & $\mathrm{H} 1, \mathrm{H} 2, \mathrm{H} 3, \mathrm{H} 4, \mathrm{H} 6, \mathrm{H} 7, \mathrm{H} 8$ & 7 \\
& $4,2,1$ & $\mathrm{H} 1, \mathrm{H} 2, \mathrm{H} 3, \mathrm{H} 4, \mathrm{H} 5, \mathrm{H} 6, \mathrm{H} 7$ & 8 \\
4 & $1,3,5$ & $\mathrm{H} 1, \mathrm{H} 2, \mathrm{H} 3, \mathrm{H} 4, \mathrm{H} 5, \mathrm{H} 6, \mathrm{H} 7, \mathrm{H} 8$ & 7 \\
& $1,2,5,4$ & $\mathrm{H} 1, \mathrm{H} 2, \mathrm{H} 3, \mathrm{H} 4, \mathrm{H} 5, \mathrm{H} 6, \mathrm{H} 7$ & 8 \\
& $3,1,2,5$ & $\mathrm{H} 1, \mathrm{H} 2, \mathrm{H} 3, \mathrm{H} 4, \mathrm{H} 5, \mathrm{H} 6, \mathrm{H} 7, \mathrm{H} 8$, & 8 \\
\hline
\end{tabular}


Jurnal Ilmiah Rekayasa dan Manajemen Sistem Informasi, Vol. 5, No. 1, Februari 2019, Hal. 34-41

e-ISSN 2502-8995, p-ISSN 2460-8181

Tabel 5. Persentase kombinasi evaluator

\begin{tabular}{ccc}
\hline $\begin{array}{c}\text { Jumlah } \\
\text { Evaluator }\end{array}$ & $\begin{array}{c}\text { Rata-rata } \\
\text { Heuristic }\end{array}$ & $\begin{array}{c}\text { Persentase } \\
\text { Heuristic }\end{array}$ \\
\hline 1 & 5 & $62 \%$ \\
2 & 7 & $87 \%$ \\
3 & 7 & $87 \%$ \\
4 & 8 & $100 \%$ \\
5 & 8 & $100 \%$ \\
\hline
\end{tabular}

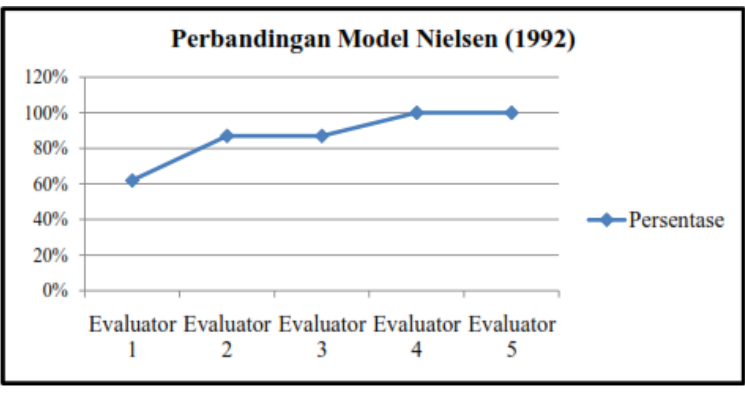

Gambar 1. Perbandingan Model Nielsen terhadap hasil empiris.

\section{KESIMPULAN}

Berdasarkan hasil evaluasi yang telah dilakukan pada website bertuahpos.com, maka dapat ditarik kesimpulan yaitu: (1) Evaluasi yang telah dilakukan dengan menggunakan metode Heuristic pada website bertuahpos.com telah berhasil menemukan masalah usability. Dari hasil perhitungan tersebut, proporsi tertinggi terdapat pada prinsip aesthetic and minimalist design dengan kode Heuristic $\mathrm{H} 7$ sebesar $22 \%$. Hal ini sebaiknya dilakukan perbaikan sesuai dengan solusi yang direkomendasikan oleh para evaluator. Proporsi yang paling rendah terdapat pada prinsip help users recognize, dialogue, and recovers from errors dengan kode $\mathrm{H} 8$ sebesar $4 \%$ hal ini tidak menjadi suatu keharusan bagi pihak perusahaan untuk melakukan perbaikan. Hal ini dikarenakan bobot tersebut tidak menjadi fokus utama dalam perbaikan; (2) Berdasarkan hasil evaluasi, rekomendasi perbaikan berupa solusi lebih difokuskan pada kode H7 dengan frekuensi masalah sebanyak lima kali.

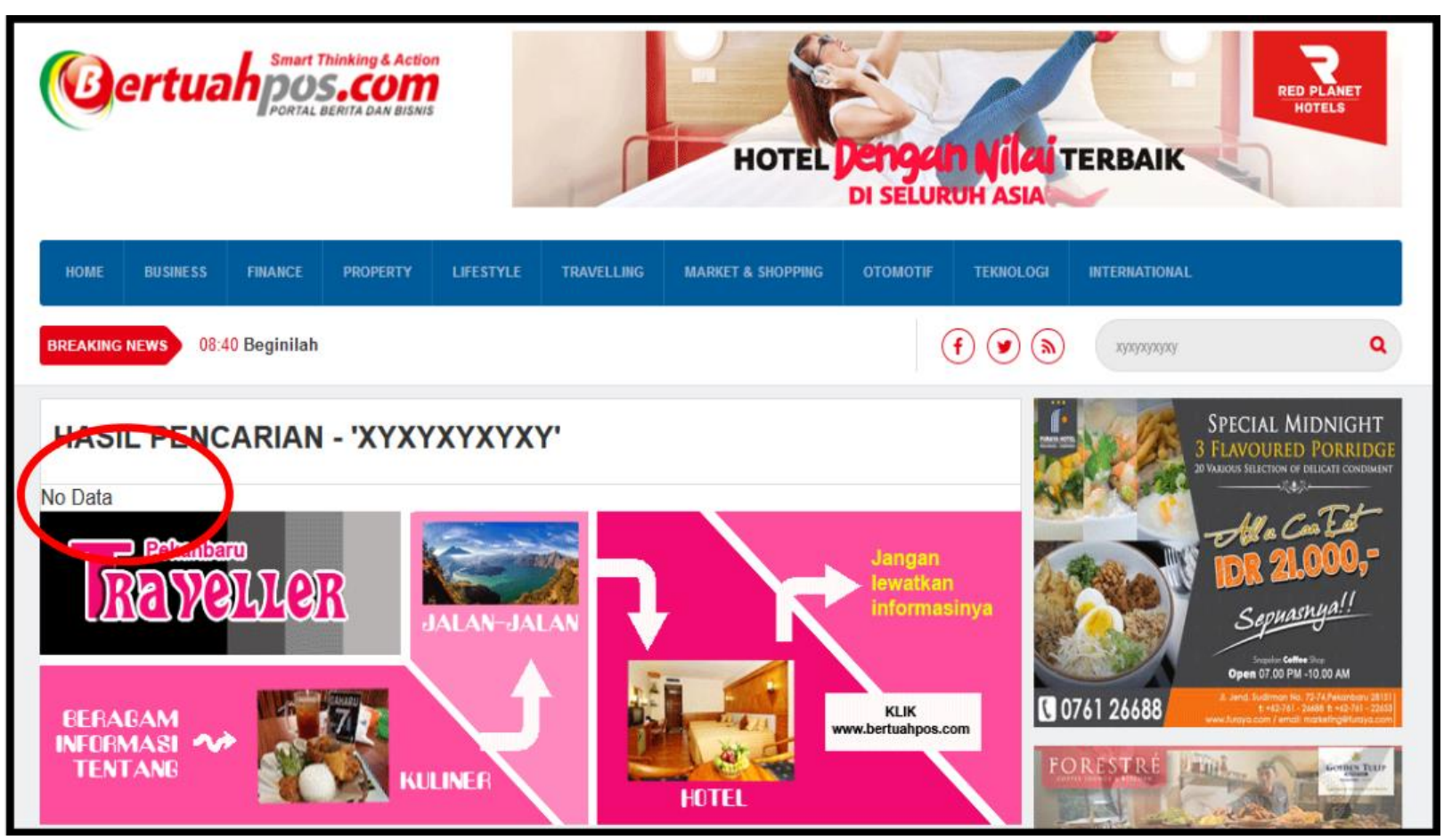

Gambar 2. Informasi pada fungsi pencarian tidak terlihat jelas 


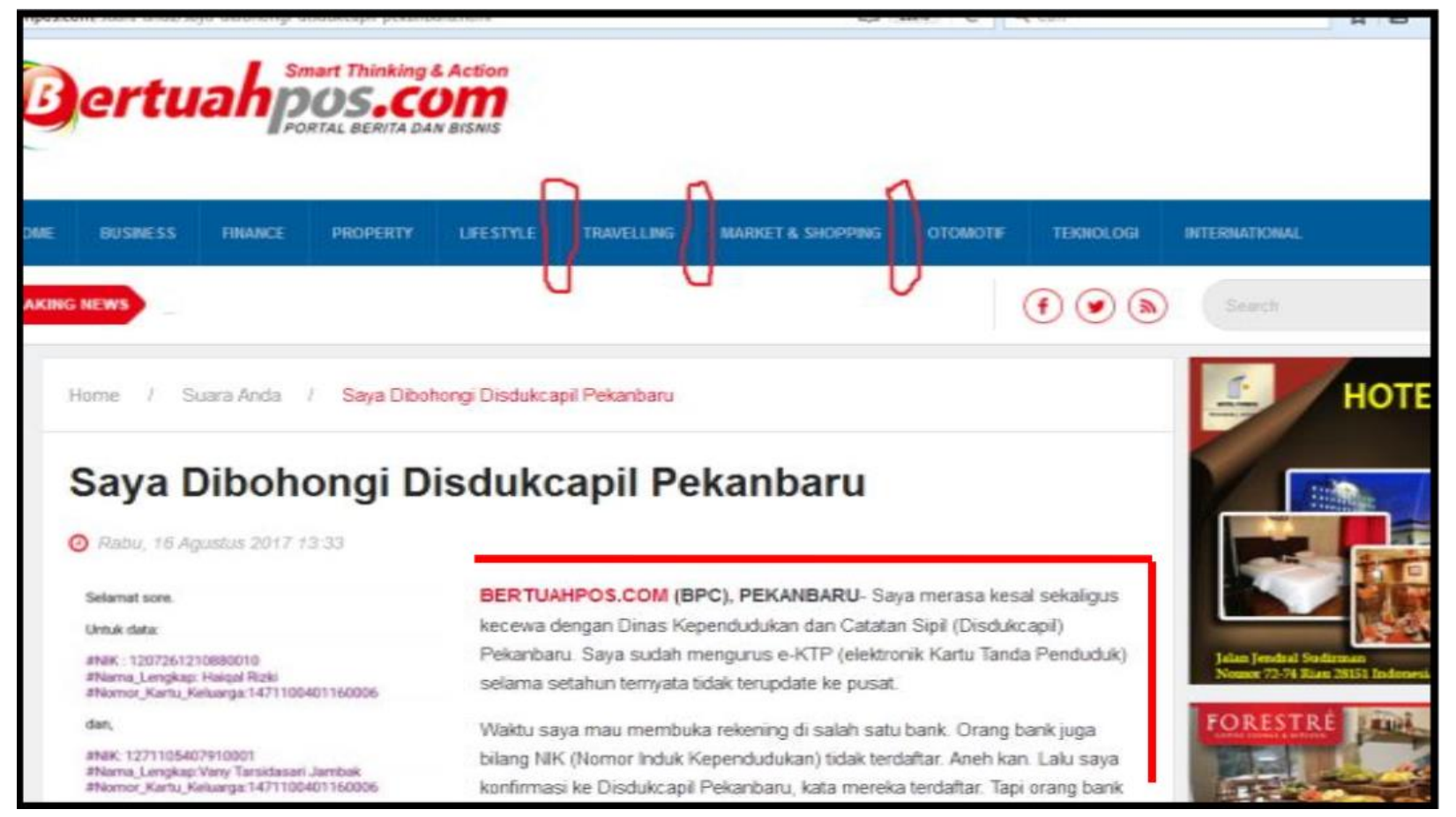

Gambar 3. Pembatas antar menu tidak terlihat jelas dan artikel terlihat tidak rapi

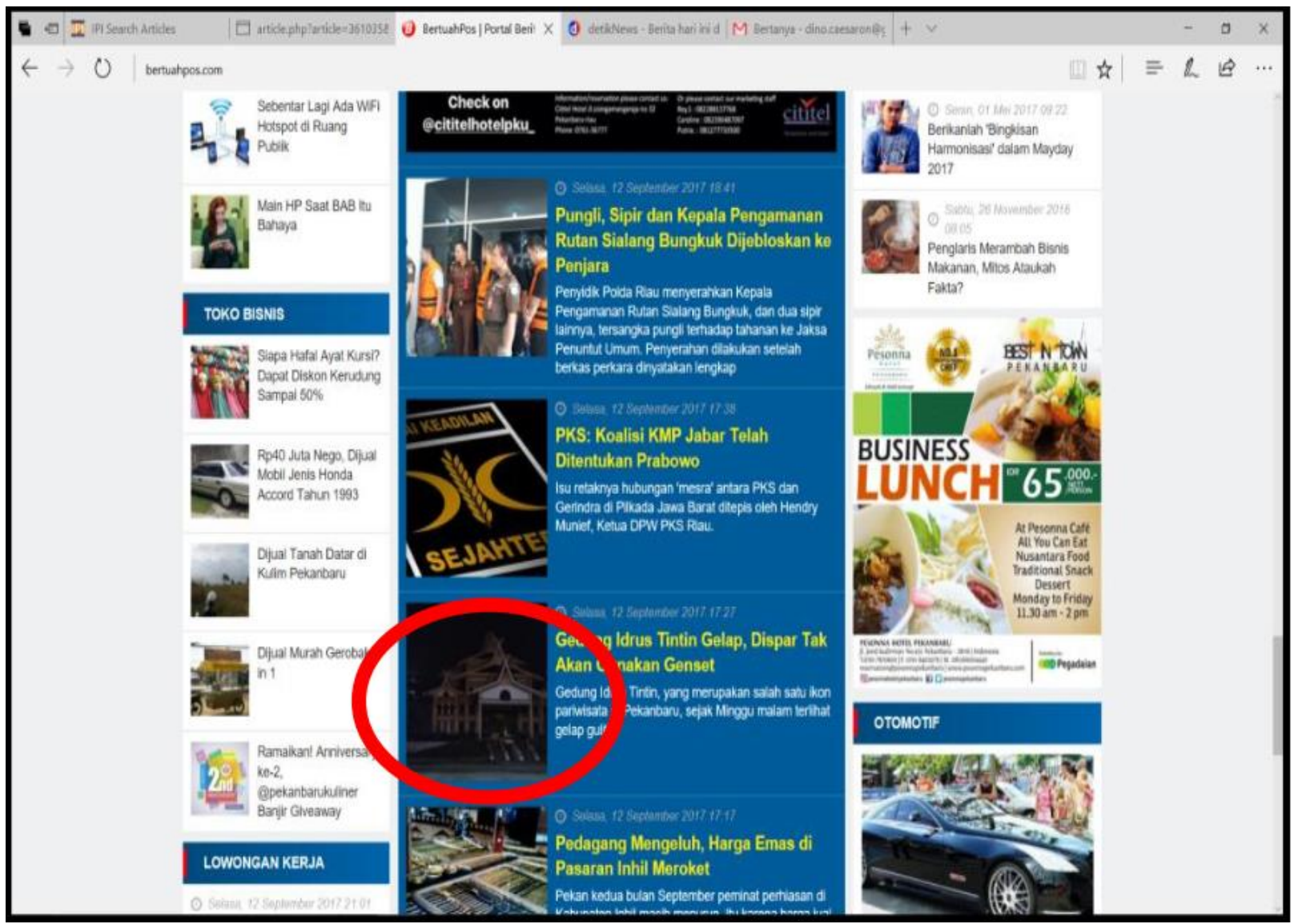

Gambar 4. Desain gambar kurang eye catching dengan judul 


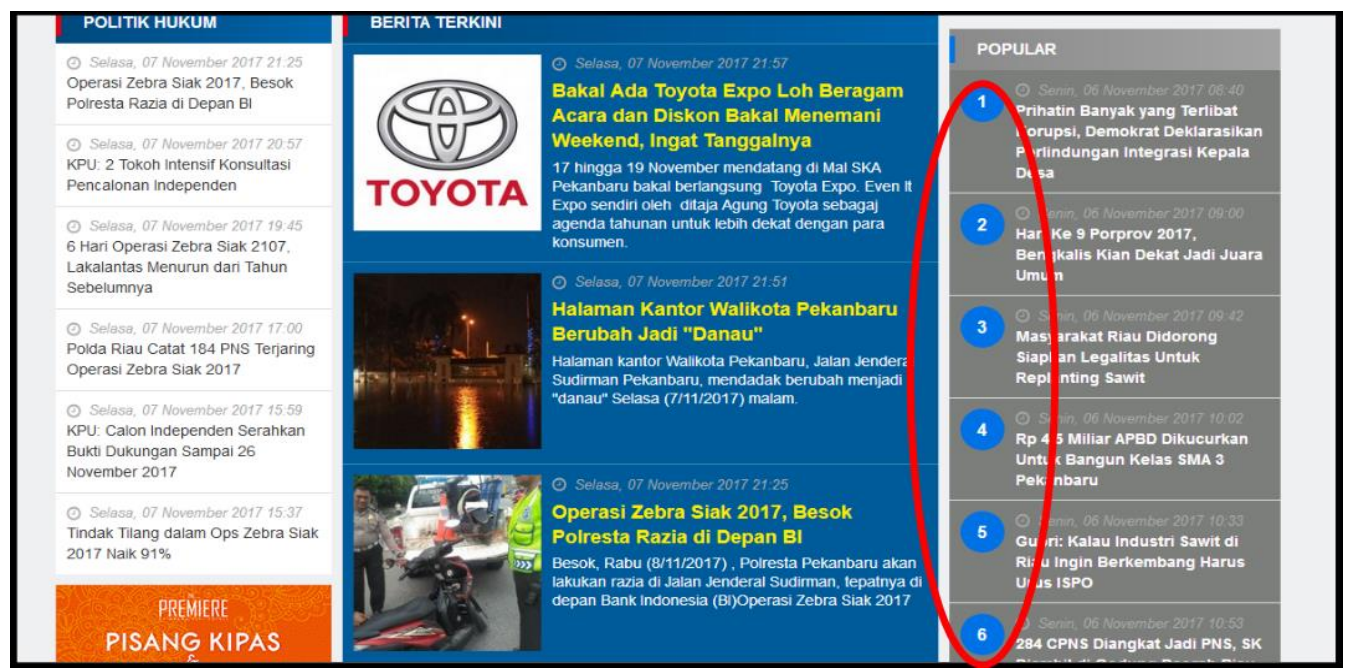

Gambar 5. Desain teralu penuh dengan informasi

\section{REFERENSI}

[1] Kustiani. 2010. Analisis Konsep Interaksai Manusia dan Komputer Pada Antarmuka Sistem Informasi JAWS (Job Access Wisth Speech) Dipusat Studi dan Layanan Difabel (PSLD) Universitas Islam Negeri Sunan Kali Jaga Yogyakarta. [Skripsi]. Fakultas Adab dan Ilmu Budaya Universitas Islam Negeri Sunan Kali Jaga, Yogyakarta.

[2] Sari, Dewi Kemala. 2010. Evaluasi Pemanfaatan Situs chem-is-try.org Dalam Pemenuhan Kebutuhan Informasi oleh Mahasiswa Departemen Kimia Fakultas Matematika dan Ilmu Pengetahuan Alam (FMIPA) Sumatera Utara.

[3] Oztekin, Asil, dkk. 2013. A Machine Learning-Based Usability Evaluation Method For Elearning Systems. ELSEVIER. Vol. 56.

[4] Islam, Anwarul., Keita Tsuji. 2011. Evaluation of Usage of University Website In Bangladesh. Journal of Library \& Information Technology. Vol. 31. No. 6. Halaman 469-479.

[5] Nurhayati, Suci, Lestarini., Handayani Putu Wuri. 2010. Pendefinisian Instrumen Evaluasi Website ECommerce Business To Consumer (B2C). Journal of Information Systems. Vol. 6. ISSN: 1412-8896.

[6] Nielsen, Jacob. 2012. Usability 101: Introduction to Usability. [Online] 18 April 2017. https://www.nngroup.com/articles/usability/101introduction-to-usability/.2012.

[7] Ridwan, Anggraeni. 2007. Pengukuran Usability Aplikasi Menggunakan Evaluasi Heuristik. Jurnal Informatika Komputer. Vol. 12. No. 3.

[8] Aealani, Khoirida., Falahah. 2012. Pengukuran Usability Sistem Menggunakan Use Questionnaire. Dalam Seminar Nasional Aplikasi Teknologi Informasi. Yogyakarta. ISSN: 1907-5022.

[9] Nimah, Iftitahu, dkk. 2011. Evaluasi Heuristic Aplikasi Open Source Groupware Sebagai Solusi Praktis E-Goverment. Industrial Electronics Seminar. Surabaya. ISBN: 978-979-8689-14-7.

[10] Purnamasari, Esty, dkk. 2012. Evaluasi Website JobsDB Mobile dengan Metode Usability Heuristic.
Seminar Ilmiah Nasional Komputer dan Sistem Intelijen. Depok Vol. 7. ISSN: 2302-3740.

[11] Dix, Alan, dkk. 2010. Human Computer Interaction. Third Edition. UK: Pearson. Halaman: 360. 2010.

[12] Nielsen, Jacob. 1995. How To Conduct A Heuristic Evaluation. [Online] 04 Januari 2017. https://www.nngroup.com/article/how/-to-conduct-aheuristicevaluation/.

[13] Winarni, Yekti Utari. 2016. Tinjauan Aspek Heuristic Untuk Mengevaluasi Tampilan Antarmuka Website Pemerintahan. Jurnal Ilmiah DASI. Vol. 17. No.1. ISSN: 1411-3201.

[14] Jaspers, Monique, W.M. A. 2009. Comparison of Usability Methods For Testing Interactive Health Technologies: Methodological Aspects and Empirical Evidence. International Journal of Medical Informatics 78. Amsterdam. 340-353.

[15] Jeffries, Robin, dkk. 1990. User Interface Evaluation in The Real World: A Comparison of Four Techniques. Software And Systems Laboratory Hpl91-03.

[16] Ssemugabi, Samuel, dan M R (Ruth) de Villiers. 2010. Effectiveness Of Heuristic Evaluation In Usability Evaluation Of Elearning Applications In Higher Education. South Africa. Research ArticleSACJ. No. 45.

[17] Savitri, Peti., Muhammad Ispani. 2015. Review Desain Interface Aplikasi Soppos Menggunakan Evaluasi Heuristik. Jurnal SIMETRIS. Vol. 6. ISSN: 2252-4983.

[18] Nielsen, Jacob. 2000. Why You Only Need to Test With 5 Users. [Online] 02 Januari 2017. https://www.nngroup.com/articles/why-you-onlyneed-to-test-with-5-users/.

[19] Rif'ah, Mega Inayati, dkk. 2016. Evaluasi Usabilitas Pada Aplikasi Program Simulasi Warna Batik. Semarang. Prosiding Seminar Nasional Multi Displin Ilmu dan Call For Papers UNISBANK. ISBN: 978979-3649-96-2. 